Tropical Journal of Pharmaceutical Research January 2021; 20 (1): 161-167

ISSN: $1596-5996$ (print); 1596-9827 (electronic)

(C) Pharmacotherapy Group, Faculty of Pharmacy, University of Benin, Benin City, 300001 Nigeria.

Available online at http://www.tjpr.org

Original Research Article

http://dx.doi.org/10.4314/tjpr.v20i1.23

\title{
A nationwide study on the knowledge, awareness, and practices towards COVID-19 in Saudi Arabia
}

\author{
Yaser M Alahmadi, Sultan S Al Thagfan \\ Department of Clinical and Hospital Pharmacy, College of Pharmacy, Taibah University, Almadinah Almunawwarah, Kingdom \\ of Saudi Arabia \\ *For correspondence: Email: yahmadi@taibahu.edu.sa
}

Sent for review: 27 July 2020

Revised accepted: 18 December 2020

\begin{abstract}
Purpose: To investigate public knowledge, awareness and practice regarding COVID-19 in Saudi Arabia.

Methods: A cross-sectional descriptive study was conducted, with a 16-item self-administered questionnaire. Data was collected using social media as the platform a day after the lockdown commenced in Saudi Arabia and data collection lasted from March 25 to April 25, 2020. Chi-square test was performed to determine the association between the variables.

Results: The results showed that $96 \%(n=1505)$ of adults were aware of the clinical symptoms of COVID-19 and $57.9 \%(n=908)$ correctly identified that a stuffy nose and sneezing were less common in persons infected with the virus. A majority $(95.4 \%, n=1495)$ agreed that there was no established therapeutic treatment for COVID-19. Further, $91.7 \%(n=1437)$ agreed that the virus could spread via respiratory droplets and only $46.2 \%(n=724)$ acknowledged that wearing face mask helped prevent transmission. The results also showed that $83.2 \%(n=1299)$ of the participants thought that visiting crowded places increased the likelihood of transmission.

Conclusion: The findings of this study reveal that adults in Saudi Arabia are cognizant of COVID-19 and maintained good attitudes and practices regarding it. Furthermore, health education programs aimed at improving awareness of the disease and appropriate control measures will be beneficial in curbing the virus pandemic.
\end{abstract}

Keywords: Saudi Arabia, Coronavirus, Pandemic, COVID-19, Flu, Symptoms

\begin{abstract}
This is an Open Access article that uses a fund-ing model which does not charge readers or their institutions for access and distributed under the terms of the Creative Commons Attribution License (http://creativecommons.org/licenses/by/4.0) and the Budapest Open Access Initiative (http://www.budapestopenaccessinitiative.org/read), which permit unrestricted use, distribution, and reproduction in any medium, provided the original work is properly credited.
\end{abstract}

Tropical Journal of Pharmaceutical Research is indexed by Science Citation Index (SciSearch), Scopus, International Pharmaceutical Abstract, Chemical Abstracts, Embase, Index Copernicus, EBSCO, African Index Medicus, JournalSeek, Journal Citation Reports/Science Edition, Directory of Open Access Journals (DOAJ), African Journal Online, Bioline International, Open-J-Gate and Pharmacy Abstracts

\section{INTRODUCTION}

A global, undefined panic has been caused by the recent deaths resulting from the most dangerous respiratory virus known to date. It was first identified in China where the Chinese Center for Disease Control and Prevention (CDC) named it the "Coronavirus disease", also known as "COVID-19" [1]. COVID-19 has an unknown etiology and is characterized by respiratory symptoms with the deposition of excess mucus in the throat and lungs. Previous studies have reported that COVID-19 is highly infectious, associated with fever, dry cough, extreme tiredness, muscle pain, and difficulty in breathing $[1,2]$. Due to the rapid global spread of the disease and the unavailability of proper treatment 
and preventative measures, the World Health Organization (WHO) declared that the COVID-19 pandemic was an international public health emergency [2,3] The family of corona viruses (CoV), previously discovered in Saudi Arabia in 2012 and called the Middle East respiratory syndrome coronavirus (MERS-CoV), contributed to 2,500 cases and 800 deaths $[4,5]$.

In Saudi Arabia, the first case of COVID-19 was diagnosed on March 2, 2020, and the second case was reported by the Ministry of Health on March 4, 2020. Since then, further cases have been reported $[6,7]$. The coronavirus pandemic may pose a great challenge to public health, health sectors, and health authorities based on the fact that millions of Muslim worshippers gather in the holy cities of Mecca and Medina in Saudi Arabia to perform the religious rituals of Umrah and Hajj every year $[8,9]$. In view of the ongoing pandemic, the government has taken unparalleled measures in these cities and in other regions of Saudi Arabia to control the spread of the virus, including the temporary suspension of entry of individuals into Medina, temporary closure of mosques $[10,11]$, lockdown of transportation, banning exit and entry into the country at both national and international levels, closing shopping malls and grocery stores, and providing isolation and care for persons suspected of or infected with the virus. Until April 14, 2020, the government has locked down the entire province of Saudi Arabia. All residents were also required to stay at home and avoid contact with others.

A vaccine is yet to be developed for COVID-19 and no specific antiviral agent is commercially available [12]. Therefore, the application of preventive measures to reduce the spread of the disease is of potentially important. The Ministry of Health $(\mathrm{MOH})$ in Saudi Arabia have published recommendations for the prevention and control of COVID-19 infection in healthcare settings [13]. This includes hand hygiene, avoiding approaching people with flu like symptoms, avoiding touching the eyes, nose, or mouth prior to washing hands, using single-use tissues while sneezing or coughing followed by immediate disposal, and wearing protective facemasks. The COVID-19 outbreak is ongoing in Saudi Arabia and several other countries. To succeed in preventing and controlling the spread of the virus, adherence to control measures is essential among the public. This is greatly influenced by their knowledge, attitude, and practices (KAP) towards COVID-19 [6]. To facilitate the management of the coronavirus in Saudi Arabia, it is important to understand the public awareness regarding COVID-19 at this difficult juncture. For this purpose, we investigated the KAP theory during this early stage of the COVID19 outbreak.

\section{METHODS}

A cross-sectional study, conducted through a well-developed, self-reported questionnaire was carried out in Saudi Arabia from March 7 to April 1st 2020 immediately after the lockdown began. During this period, we collected the data using the social media platform. Participants included Arabic-speaking adults who currently lived in Saudi Arabia. The exclusion criteria were nonArabic speakers, illiterates or, those who cannot read Arabic, and those who were outside the country were excluded. This study received approval from the research ethics committee of College of Pharmacy, Taibah University (COPTU-REC), Madinah, Saudi Arabia (approval no. COPTU-REC/20200420), and followed the guidelines of the Declaration of Helsinki, as well as appropriate safeguards regarding the rights and welfare of the human participants [14].

The questionnaire was developed through an extensive review of the literature published in this regard [1] and modified to Arabic using the forward back translation procedure. The simple random sampling technique was used to collect the data using social media platforms. We defined simple random sampling technique is a subset of a statistical population in which each member of the subset has an equal probability of being chosen. Responses were recorded anonymously. The survey was about the clinical presentations and management of COVID-19. The online survey consisted of three sections. The first section included questions related to the participants' demographics such as age, marital status, education level, occupation, and regional location within Saudi Arabia.

The second section assessed the participants' clinical knowledge of the disease, routes of transmission, and prevention and control measures and consisted of a total of 11 questions with multiple choice answers (Yes/No/l don't know). The third part of the questionnaire mainly assessed the participants' attitudes and practices towards COVID-19, and comprised of a total of 4 questions with binary answers, adopted and modified from a previous study conducted by [1]. A pilot study, conducted among 20 randomly selected subjects, was used to evaluate the responses and measure the validity of the questionnaire to optimize data collection. The reliability value for the knowledge questionnaires was 0.74, awareness, 0.72 and attitudes were 
0.81. The study tools were amended based on the results of the pilot study.

\section{Data analysis}

The data were analyzed using Microsoft Excel 2007 and then transferred into the statistical package for social science version 24 (SPSS) Statistics version 24. For descriptive analysis, results were presented as numbers, percentages. Chi-square test was performed to determine the association between the variables.

\section{RESULTS}

A total of 1572 participants undertook the survey. A total of 5 responses from participants were excluded from the research due to incompleteness of the questionnaires. Therefore, 1567 respondents completely answered the survey. All participants were from Saudi Arabia. Of the respondents, approximately $21 \%$ were aged between 18 and 30 years, $42.8 \%$ were aged between 31 to 45 years, and $36.2 \%$ were aged above 46 years. Most of the participants were married $(78.7 \%)$. University graduates accounted for $61.3 \%$ of participants, while $20 \%$ were secondary school graduates. The detailed socio demographics of the subjects has been given in Table 1.
The study showed that the lowest correct response was related to the identification of the clinical symptoms of the disease (42\%). The results of the study found that majority of the subjects (96\%) were aware that fever, dry cough, body pains, and flue were the main symptoms of the COVID-19, while only $(1.1 \%)$ and $(2.8 \%)$ of them were unaware of this. Nearly all of the respondents $(95.4 \%)$ agreed that as of now, there is no effective cure for COVID-19, but early symptomatic and supportive treatment can help most patients to recover from the infection. In addition, $78.9 \%$ agreed or correctly identified that not all persons infected with COVID-19, but those who are elderly and have chronic illnesses, are more likely to develop severe and possibly fatal symptoms (Table 2).

Regarding the routes of transmission, majority of the respondents $(91.7 \%)$ agreed that virus spreads via the respiratory droplets of infected individuals. Only $37.4 \%$ of the participants agreed that eating or contacting wild animals could cause the coronavirus infection, while most of them $62.6 \%$ disagreed with this. Interestingly, $85.4 \%$ of the participants said that persons with COVID-19 could not infect others with the virus when a fever was not present (Table 2).

Table 1: Demographic distribution of participants $(n=1567)$

\begin{tabular}{|c|c|c|c|}
\hline Demographic data & Number of participants (n) & Frequency (\%) & $P$-value \\
\hline \multicolumn{4}{|l|}{ Gender } \\
\hline Male & 981 & 62.6 & \\
\hline Female & 586 & 37.4 & $<0.001$ \\
\hline \multicolumn{4}{|l|}{ Age group } \\
\hline $18-25$ & 186 & 11.9 & \\
\hline $26-30$ & 143 & 9.1 & $<0.001$ \\
\hline $31-45$ & 670 & 42.8 & \\
\hline Over 46 & 568 & 36.2 & \\
\hline \multicolumn{4}{|l|}{ Marital status } \\
\hline Married & 1233 & 78.7 & \\
\hline Unmarried & 272 & 17.4 & $<0.001$ \\
\hline Widowed or divorced & 62 & 4 & \\
\hline \multicolumn{4}{|l|}{ Education } \\
\hline Primary school & 70 & 4.4 & \\
\hline Secondary school & 313 & 20 & $<0.001$ \\
\hline Bachelor's degree & 960 & 61.3 & \\
\hline Master's degree & 224 & 14.3 & \\
\hline \multicolumn{4}{|l|}{ Employment status } \\
\hline Employed & 967 & 61.7 & \\
\hline Unemployed & 600 & 38.3 & $<0.001$ \\
\hline \multicolumn{4}{|c|}{ Province of Saudi Arabia } \\
\hline North & 137 & 8.7 & \\
\hline East & 75 & 4.8 & \\
\hline West & 1186 & 75.7 & $<0.001$ \\
\hline South & 35 & 2.2 & \\
\hline Central & 134 & 8.5 & \\
\hline
\end{tabular}


Table 2: Awareness of the clinical presentations and transmission route of COVID-19

\begin{tabular}{lcc}
\hline Question & $\begin{array}{c}\text { Correct answer } \\
\mathbf{n}(\%)\end{array}$ & $\begin{array}{c}\text { Incorrect answer } \\
\mathbf{n}(\%)\end{array}$ \\
\hline COVID-19 is associated with fever, fatigue, dry cough, and body pains. & $1505(96 \%)$ & $62(4.0 \%)$ \\
$\begin{array}{l}\text { Stuffy nose, runny nose, and sneezing are not the symptoms of } \\
\text { COVID-19 }\end{array}$ & $608(57.9 \%)$ & $659(42 \%)$ \\
$\begin{array}{l}\text { As of now, there is no effective treatment for COVID-19, but early } \\
\text { symptomatic and supportive treatment can help most patients to }\end{array}$ & $1495(95.4 \%)$ & $73(4.6 \%)$ \\
recover. & $1236(78.9 \%)$ & $331(21.2 \%)$ \\
$\begin{array}{l}\text { Not all persons with COVID-19 will develop serious symptoms. Only } \\
\text { those who are elderly or have chronic illnesses are more likely to } \\
\text { develop the disease. }\end{array}$ & $586(37.4 \%)$ \\
$\begin{array}{l}\text { Eating meat or coming in contact with animals could result in an } \\
\text { infection by COVID-19 }\end{array}$ & $981(62.6 \%)$ & $230(14.6 \%)$ \\
$\begin{array}{l}\text { Persons with COVID-19 cannot transmit the virus to others when a } \\
\text { fever is not present }\end{array}$ & $1337(85.4 \%)$ & $130(8.3 \%)$ \\
COVID-19 is transferred via respiratory droplets of infected individuals & $1437(91.7 \%)$ & 5 \\
\hline
\end{tabular}

Approximately $46.2 \%$ of the subjects acknowledged that wearing facemasks helped in preventing the likelihood of transmission of infection, while a similar number of the respondents $(46.8 \%)$ disagreed with this. Furthermore, the majority of participants disagreed that children and young adults did not need to take protective measures to prevent an infection from the virus. Nearly all of the respondents $(99 \%)$ were aware that crowded places should be avoided to prevent the possibility of contracting the COVID-19 viral infection (Table 3).
The study also showed that the majority of participants had travelled to crowded places $(83.2 \%)$ and worn a facemask $(60.1 \%)$ recently. The majority of the subjects felt that the coronavirus would eventually be controlled (85.1 $\%)$. Only a small proportion of individuals opposed this statement $(0.9 \%$ said 'No', $14 \%$ said 'I don't know'). In addition to this, almost all of the participants were confident that COVID-19 would ultimately be eradicated. A statistically significant difference between the answers of the participants for each question related to the clinical presentation and routes of transmission of COVID-19 (Table 4).

Table 3: Awareness of the prevention and control of COVID-19

\begin{tabular}{lll}
\hline Question & $\begin{array}{l}\text { Correct answer } \\
\mathbf{n}(\%)\end{array}$ & $\begin{array}{l}\text { Incorrect answer } \\
\mathbf{n}(\%)\end{array}$ \\
\hline $\begin{array}{l}\text { Individuals can wear facemasks to prevent an infection from COVID- } \\
19\end{array}$ & $724(46.2 \%)$ & $733(46.8 \%)$ \\
$\begin{array}{l}\text { It is not compulsory for children and young adults to take measures } \\
\text { to prevent the infection }\end{array}$ & $1518(96.9 \%)$ & $24(1.5 \%)$ \\
$\begin{array}{l}\text { To prevent being infected by COVID-19, individuals should avoid } \\
\text { going to crowded places }\end{array}$ & $1552(99 \%)$ & $6(0.4 \%)$ \\
$\begin{array}{l}\text { Isolation and treatment of people with COVID-19 are effective ways } \\
\text { to reduce the spread of the virus }\end{array}$ & $1555(99.2 \%)$ & $6(0.4 \%)$ \\
\hline
\end{tabular}

Table 4: Attitudes of participants towards COVID-19

\begin{tabular}{lccc}
\hline Responses & $\mathbf{N}$ & $\mathbf{\%}$ & $\boldsymbol{P}$-value \\
\hline Have recently visited any crowded places & 1299 & 83.2 & \\
Wears a facemask when one leaves home & 936 & 60.1 & \\
Believe that COVID-19 will ultimately be eradicated & 1469 & 93.7 & \\
\hline Do you think that COVID-19 will be successfully controlled? & & & \\
$\quad$ Agree & 1334 & 85.12 & $<.001$ \\
Disagree & 14 & 0.9 & \\
I don't know & 219 & 14 & \\
\hline
\end{tabular}




\section{DISCUSSION}

There are a limited number of studies assessing the knowledge of the general public related to the clinical presentation, attitudes, and practices around the ongoing coronavirus COVID-19 pandemic. Insufficient literature is available based on the knowledge and attitudes in practice around COVID-19. However, literature has previously been reported on MERS $[4,5,8]$. This study would significantly contribute to the safety, prevention, and control measures around COVID-19 and serve as a reference for upcoming studies.

The study findings indicate that most participants were aware of the COVID-19 situation in Saudi Arabia. For example, when asked about the clinical symptoms of the disease, majority of the participants identified these correctly. Additionally, most of the participants agreed that there was no current cure or standard treatment for COVID-19. These results were in accordance with the guidelines published by $\mathrm{WHO}$, Ministry of Health, and CDC [12,13]. Based on these findings, it can be concluded that the subjects had good awareness of the clinical presentations of COVID-19, similar to a previous study [1].

During the MERS epidemic of 2012, $91.2 \%$ of the study participants were familiar with mode of transmission of the disease [3,8]. This value is similar to that of our findings $(91.7 \%)$. The awareness among subjects around COVID-19 is based on the measures taken by the government by restricting the travel and movement of residents, which focuses on the prevention and control of the disease. This then encourages all citizens to fight the battle against COVID-19. The vast majority of participants surveyed also exhibited good awareness towards preventative and control measures: Almost all the respondent agreed that avoiding crowded places, helps to contain the spread of COVID-19, similar to a previous study in China where $96.4 \%$ of the residents were reported to take such measures to control the infection [1].

Similarly, approximately $99.2 \%$ of the participants agreed that isolation and treatment of infected people were effective in reducing the spread of the virus. Interestingly, the results of this study showed that less than half of the participants agreed that wearing a protective facemask helped in preventing the spread of the disease, which is significantly lower than a previous study where $98 \%$ of participants agreed that wearing a facemask helped in controlling the spread of infection $[1,15]$. This variation in the awareness regarding the protective measures may be due to participants being unaware of the availability of facemasks in the market or due to the lack of interest in wearing the facemasks as it may hamper everyday activity.

Despite all the ongoing initiatives, the COVID-19 pandemic is still an international crisis. Prevention and control of the virus varies based on individual knowledge, attitude, and practices. A virus-free environment is possible only when all individuals follow the guidelines prescribed by healthcare authorities such as washing hands, avoiding going to crowded places, and wearing the protective facemasks to combat the spread of virus $[12,13]$.

The findings of this study also demonstrated that the majority of participants travelled during the pandemic, and just over half of them wore a protective facemask when leaving home. These unsafe practices suggest the need for further awareness programs to ensure better control of the pandemic. However, compared to studies performed in Iran and China where most participants observed good practices towards COVID-19 [1,15] in our study, nearly $40 \%$ of the participants did not wear a protective facemask. This is higher than that previously reported in Iran where $25 \%$ of the subjects neglected wearing a facemask. This kind of unsafe practice was reported to be higher in males and was also strongly associated with poor knowledge of the disease, poor economic status, and lack of awareness about the disease [15]. However, other studies suggested that males and adolescents were associated with risk taking behaviors, [16-18] which could potentially contribute to the negligence observed in this study.

\section{Limitations of the study}

The limitations of the present study included the short duration and not covering all the regions of Saudi Arabia but mainly relying on the author's connectivity, with the local peoples who are currently living in Saudi Arabia which restrict the generalizability of the findings. Secondly since the virus COVID can be transmit through droplets or close contact, a web-based survey was chosen to decrease the chances of transmission however, some biases such as lack of access to the social media, internet and lack of education may have affected the results.

\section{CONCLUSION}

The findings of this study suggest that in general, Saudis demonstrated good knowledge, positive 
attitudes, and reasonable practices towards the COVID-19 pandemic during the early period of the outbreak. However, some aspects need to be further improved on. Healthcare authorities are encouraged to establish health education programs, via the various channels of social media, to quickly and effectively target all individuals and better educate them on COVID19 , encouraging positive attitudes and safe practices. By enhancing the knowledge of the public through healthcare channels, and collaborating with authorities to provide support for all citizen, COVID-19 can be adequately controlled.

\section{DECLARATIONS}

\section{Acknowledgement}

The author of this study extend their appreciation to Renad Alahmadi and Rafif Alahmadi for their help in data collection.

\section{Conflict of interest}

No conflict of interest is associated with this work.

\section{Contribution of authors}

We declare that this work was done by the authors named in this article and all liabilities pertaining to claims relating to the content of this article will be borne by the authors.

\section{Open Access}

This is an Open Access article that uses a funding model which does not charge readers or their institutions for access and distributed under the terms of the Creative Commons Attribution License (http://creativecommons.org/licenses/by/ 4.0) and the Budapest Open Access Initiative (http://www.budapestopenaccessinitiative.org/rea d), which permit unrestricted use, distribution, and reproduction in any medium, provided the original work is properly credited.

\section{REFERENCES}

1. Zhong BL, Luo W, Li HM, Zhang QQ, LiU XG, Li WT, Li Y. Knowledge, attitudes, and practices towards COVID-19 among Chinese residents during the rapid rise period of the COVID-19 outbreak: a quick online cross-sectional survey. Int J Biol Sci. 2020;16(10):1745-1752.

2. World health organization (WHO). Corona virus disease (COVID-19) Pandemic. Available on https://www.who.int/emergencies/diseases/novelcoronavirus-2019. Last accessed on April 12020.

3. Barry M, Al Amri M, Memish ZA. COVID-19 in the Shadows of MERS-CoV in the Kingdom of Saudi Arabia. Journal of Epidemiology and Global Health, 2020; 10(1), 1-3.

4. Cascella M, Rajnik M, Cuomo A., Dulebohn S. C, \& Di Napoli R. Features, evaluation and treatment coronavirus (COVID-19). In StatPearls [Internet]. StatPearls Publishing 2020.

5. Asaad AM, El-Sokkary RH, Alzamanan MA, El-Shafei M. Knowledge and attitudes towards Middle East respiratory syndrome-coronavirus (MERS-CoV) among health care workers in south-western Saudi Arabia. East Mediterr Health J. 2020; 1: 25.

6. Arab News. Saudi Arabia announces first case of coronavirus". Available on https://www.arabnews.com/ node/1635781/saudi-arabia last accessed on april 1 2020.

7. Arab News. Saudi Arabia detects second coronavirus case. Available on https://www.arabnews.com/ node/1636926/saudi-arabia. Last accessed on april 1 2020.

8. Al-Mohrej OA, Al-Shirian SD, Al-Otaibi SK, Tamim HM, Masuadi EM, Fakhoury HM. Is the Saudi public aware of Middle East respiratory syndrome? Journal of infection and public health. 2016 May 1;9(3):259-266.

9. Almutairi KM, Al Helih EM, Moussa M, Boshaiqah $A E$, Saleh Alajilan A, Vinluan JM, et al. Awareness, attitudes, and practices related to coronavirus pandemic among public in Saudi Arabia. Fam Comm Health. 2015; 38(4): 332-340.

10. Khalek HA, Nomiyama C. Saudi Arabia temporarily suspends entry of GCC citizens to Mecca and Medina: foreign ministry. Reuters. Archived from the original on 29 February 2020. Retrieved 2020-02-29.

11. Arab News. Saudi Arabia closes Grand Mosque, Prophet's Mosque between night and morning prayers. 5 March 2020. Archived from the original on 5 March 2020. Available from https://www.arabnews.com/ node/1637341/saudi-arabia. Retrieved 6 March 2020.

12. CDC. 2019 Novel Coronavirus. Prevention \& Treatment. Cent. Disease Control Prev. 2020. Available online: https://www.cdc.gov/coronavirus/2019ncov/about/prevention-treatment.html.

13. Ministry of health. Novel Coronavirus (COVID-19). Available at https://www.moh.gov.sa/en/HealthAware ness/EducationalContent/Corona/Pages/corona.aspx.La st Accessed on April 2, 2020.

14. General Assembly of the World Medical Association. World Medical Association Declaration of Helsinki: General Assembly of the World Medical Association. World Medical Association Declaration of Helsinki.

15. Erfani A, Shahriarirad R, Ranjbar K, Mirahmadizadeh A \& Moghadami M. Knowledge, Attitude and Practice toward the Novel Coronavirus (COVID-19) Outbreak: A Population-Based Survey in Iran. [Submitted]. Bull 
World Health Organ. E-pub: 30 March 2020. doi: http://dx.doi.org/10.2471/BLT.20.256651.

16. Cobey KD, Stulp G, Laan F, Buunk AP, Pollet TV. Sex differences in risk taking behavior among Dutch cyclists. Evolutionary psychology: an Int $\mathrm{J}$ Evolutionary Approaches to Psychology and Behavior. 2013; 11(2): 350-364. Epub 2013/05/16.
17. Pawlowski B, Atwal R, Dunbar RIM. Sex Differences in Everyday Risk-Taking Behavior in Humans. Evolutionary Psychology. 2008; 6(1): 147470490800600. Epub 2008/01/01.

18. Duell N, Steinberg L, Icenogle G, Chein J, Chaudhary N, Di Giunta $L$, et al. Age patterns in risk taking across the world. J Youth Adoles. 2018; 47(5): 1052-1072. Epub 2018/05/01. 